\title{
Pulmonary Radiological Findings in Patients with Acute Myeloid Leukemia and Their Relationship to Chemotherapy and Prognosis: A Single-Center Retrospective Study
}

\author{
Akut Miyeloid Lösemili Hastalarda Akciğer Radyolojik Bulgularının \\ Kemoterapi ve Hastalı̆̆ın Prognozu ile İlişkisi: Tek Merkezli \\ Retrospektif Çalışma
}

Mehmet S Buğdacı ${ }^{1}$, Halil Yanardağ ${ }^{1}$, M. Cem Ar², Teoman Soysal ${ }^{3}$, Süleyman Coşkun ${ }^{1}$, Sabriye Demirci ${ }^{1}$

${ }^{1}$ Istanbul University, Cerrahpaşa School of Medicine, Department of Pneumophysiology, Division of Internal Medicine, İstanbul, Turkey ${ }^{2}$ İstanbul Training and Research Hospital, Department of Hematology, İstanbul, Turkey

${ }^{3}$ İstanbul University, Cerrahpaşa School of Medicine, Department of Hematology, Division of Internal Medicine, İstanbul, Turkey

\begin{abstract}
Objective: Acute myeloid leukemia (AML) is the most common acute leukemia in adults. Pulmonary are among the most common causes of mortality in AML. This single-center retrospective study aimed to evaluate the relationship between radiological findings of pulmonary at presentation and post chemotherapy on prognosis and clinical outcome in a group of AML patients.
\end{abstract}

Material and Methods: The study included 278 AML patients. Clinical and radiological findings, laboratory findings, and microbiological culture results were evaluated. Pulmonary complications at presentation and post chemotherapy were compared.

Results: Pulmonary complications were observed in 53 of the patients (19\%). Mean age of the patients with and without pulmonary complications was $43.1 \pm 15.2$ years and $38.8 \pm 16.3$ years, respectively $(P<0.001)$. Pulmonary complications were not correlated with gender, AML subtype, or the serum lactate dehydrogenase (LDH) level. The most common cause of pulmonary complications was infection. Pulmonary complications were observed in $29 \%$ and $71 \%$ of the patients at presentation and post chemotherapy, respectively.

Conclusion: Pulmonary complications were observed more frequently at presentation in neutropenic AML patients of advanced age. The mortality rate was higher among the AML patients that had pulmonary complications at presentation.

Key Words: Acute myeloid leukemia, Pulmonary disease, Radiological findings

Address for Correspondence: Mehmet S BUĞDACI, M.D.,

İstanbul Üniversitesi, Cerrahpaşa Tıp Fakültesi, Fatih, İstanbul, Turkey

Phone: +90 2124143414 E-mail: msbugdaci@gmail.com 


\section{Özet}

Amaç: Akut miyeloid lösemi (AML) erişkinde en sık görülen akut lösemidir. AML'de mortaliteyi yol açan en önemli sebeplerden biri pulmoner olaylardır. Bu retrospektif tek merkezli çalışmanın amacı tanı anında ve kemoterapi sonrası gelişen radyolojik akciğer bulgularının hastalığın klinik gidişi ve prognozu üzerine etkisinin araştırılmasıdır.

Gereç ve Yöntemler: Çalışmaya 278 AML hastası dahil edildi. değerlendirildi. Tanı anındaki ve kemoterapi sonrası pulmoner bulgular, hastalara ait klinik ve radyolojik bulgular, laboratuvar verileri ve mikrobiyolojik kültür sonuçları ile değerlendirildi.

Bulgular: Pulmoner olaylar hastaların 53'ünde (\%19) görüldü. Pulmoner bulguları olan ve olmayan hastaların ortalama yaşları sırasıyla $43.1 \pm 15.2$ ve $38.8 \pm 16.3$ olarak bulundu $(p<0,001)$. Akciğer bulguları ile cinsiyet, AML alt tipi ve LDH düzeyleri arasında ilişki saptanmadı. En sık rastlanılan pulmoner olay enfeksiyondu. Pulmoner olaylar hastaların \%29'unda tanı anında, \%71'inde tedavi sonrası gözlendi.

Sonuç: Pulmoner olaylar ileri yaştaki, nötropenik hastalarda tanı anında daha sık gözlendi. Tanı anında pulmoner komplikasyonu bulunan AMLli hastalarda mortalite daha yüksek bulundu.

Anahtar Sözcükler: Akut miyeloid lösemi, Pulmoner hastalık, Radyolojik bulgular

\section{Introduction}

Acute myeloid leukemia (AML) is a heterogeneous group of neoplastic disorders characterized by malignant proliferation of myeloid precursor cells. It is the most common form of acute leukemia in adults. [1,2,3] The prognosis of acute leukemias is poor, despite improvements in supportive and definitive therapies.[4] Severe pulmonary complications, including acute pulmonary insufficiency and infectious pneumonia, frequently occur in patients with acute leukemia. $[5,6]$ Such pulmonary complications may be of infectious or non-infectious origin. Pulmonary infections are the most important cause of morbidity and mortality in patients with hematological malignancies undergoing chemotherapy.[7] Furthermore, high mortality rates nearly $60 \%$ were reported in leukemia patients with radiologically evident pulmonary infiltration. [8]

The bulk of data on pulmonary findings in patients with AML consists primarily of chemotherapy-related complications. [6,7,9-11] Data are lacking on other aspects of pulmonary findings in AML, such as the association between AML subtypes and pulmonary complications, and the correlation between pulmonary complications at presentation and prognosis. As such, the aim of the present single-center retrospective study was to evaluate the relationship between radiological findings of pulmonary complications at presentation and post chemotherapy on prognosis and clinical outcome in patients with AML.

\section{Materials and Methods}

Presentation and follow-up records of $1066 \mathrm{pa}$ tients with hematological malignancies that presented to University of Istanbul, Cerrahpaşa School of Medicine,
Hematology Department, between 1995 and 2006 were retrospectively reviewed. There were 475 patients diagnosed as acute leukemia, of which 278 with AML were included in the study. AML was diagnosed based on morphology and immunophenotyping. The patients were classified according to French-American-British (FAB) criteria. Flow cytometry was used for immunophenotyping.

\section{Methodology of radiographic studies}

Thoracic high-resolution computed tomography (HRCT) was performed using a Siemens Somatom Plus (Siemens, Erlangen, Germany) scanner during breathholding at full inspiration, according to Gevenois et al [12]. At the beginning of the procedure radiographic fields were marked on digital topograms. Using a cross sectional thickness of $1 \mathrm{~mm}$ and a cross sectional interval of $10 \mathrm{~mm}$, deep inspiration images of the whole lung parenchymafrom apex to base-were obtained using the high-spatialfrequency (bone) reconstruction algorithm. Every section over the diaphragm for each lung was evaluated separately.

\section{Definitions}

Consolidation was considered homogeneous amorphous opacities observed via air bronchogram to obscure many of the underlying vessels. Ground-glass appearance was characterized as a patchy or diffuse hazy increase in lung opacity that did not obscure the underlying vessels. Radiologically, nodules are focal, rounded opacities of varying size, with either well- or ill-defined borders. In the present study, rounded opacities without any specific features were simply defined as non-specific nodular opacity. Air-containing nodules were considered cavitary nodules. Thoracic findings were classified as pleural, parenchymal, 
and pleuroparenchymal, according to radiological appearance. Lesions were considered parenchymal if they involved the pulmonary tissue and bronchial tree. Pleural thickening was associated with fibrosis, pleural effusion, or pleural involvement.

Radiological, clinical, and laboratory findings were evaluated together, so as to determine their etiology. Consolidation and abscesses were considered to be due to bacterial agents initially if supportive clinical findings were present. Nodules without specific characteristics, such as a centrilobular nodule or acinar nodule ( \pm halo finding), were considered to be of fungal origin. Cavitary lesions were diagnosed as tuberculosis if confirmed via microbiological culture results. Radiological diagnosis of pulmonary embolism was based on spiral CT findings or high-probability ventilation/perfusion scintigraphy. Invasive pulmonary aspergillosis was diagnosed according to EORTC/MSG consensus criteria.[13] Leukostasis was considered a leukocyte count $>100 \times 10^{9} \mathrm{~L}^{-1}$ and the presence of pulmonary symptoms (dyspnea and diffuse interstitial infiltrates chest radiographs), only after having excluded other plausible causes. The diagnosis of bacterial pneumonia was based on the presence of a pathogen concentration $>10^{3} \mathrm{CFU} \mathrm{mL} \mathrm{m}^{-1}$ in culture. Respiratory findings were grouped as those that were observed at presentation and those that occurred post chemotherapy.

\section{Drugs}

Cytosine arabinoside (100-200 $\mathrm{mg} \mathrm{m}^{-2}$ on $\mathrm{d} \mathrm{1-7)} \mathrm{and}$ daunorubicin (45 $\mathrm{mg} \mathrm{m}^{-2}$ on $\mathrm{d} 1-3$ ), idarubicin (12 mg $\mathrm{m}^{-2}$ on d 1-3), or mitoxantrone (12 $\mathrm{mg} \mathrm{m}^{-2}$ on d 1-3) were administered as induction treatment for AML. High-dose cytosine arabinoside (1.5-3 $\mathrm{g} \mathrm{m}^{-2} \mathrm{q} 12 \mathrm{~h}$ on $\mathrm{d} 1,3$, and 5 [6 doses]) was administered for consolidation purposes following remission. Regimens containing all-transretinoic acid (ATRA) and idarubicin were used for remission induction and consolidation in patients with acute promyelocytic leukemia.

Broad-spectrum beta-lactam antibiotics and carbapenems with or without aminoglycoside were administered in febrile patients with neutropenia $\left(<500 \mathrm{~mm}^{-3}\right)$. The addition of glycopeptide antibiotics and/or antifungal agents, as well as re-evaluation of initial antibiotic therapy, were usually carried out according to IDSA guidelines. $[14,15]$ The study protocol was approved by the Istanbul University, Cerrahpaşa School of Medicine Ethics Committee.

\section{Statistics}

Parametric variables are presented as mean \pm standard deviation (mean $\pm \mathrm{SD}$ ). Non-parametric data were evalu- ated using the chi-square or Pearson's correlation tests, as appropriate. Student's t test was used for comparison of parametric data. A P value less then 0.05 was considered to be statistically significant. SPSS v.12.0 for Windows was used for statistical evaluation.

\section{Results}

The study included 278 AML patients. In all, 169 (60.7\%) were male (mean age: $39.2 \pm 16$ years) and 109 (39.3\%) were female (mean age: $40.3 \pm 16.5$ years). Among the patients, 241 (86.7\%) had de novo AML and 37 (13.3\%) had AML secondary to chronic myeloid leukemia, myelodysplastic syndrome, sideroblastic anemia, aplastic anemia, or chemotherapy. In total, 47 (16.9\%) patients were aged $\geq 65$ years.

Pulmonary findings were observed in 53 (19.1\%) of the 278 AML cases (Table 1 and the Figure). Mean age of the patients with and without radiologically confirmed pulmonary complications was $43.1 \pm 15.2$ years and 38.8

Table 1: The etiology of radiologically confirmed pulmonary complications and the frequency of Aspergillus infection in the AML patients $(\mathrm{n}=53$ ), according to EORTC/MSG consensus criteria.

\begin{tabular}{|c|c|}
\hline Cause & n (\%) \\
\hline Infection & $30(56.6)$ \\
\hline Bacterial $^{*}$ & $8(15.0)$ \\
\hline Bacterial $^{* *}$ & $7(13.3)$ \\
\hline Mycobaterium tuberculosis ${ }^{* * *}$ & $1(2.0)$ \\
\hline \multicolumn{2}{|l|}{ Aspergillus fumigatus } \\
\hline Proven & $2(3.8)$ \\
\hline Probable & $3(5.7)$ \\
\hline Possible & $9(17.0)$ \\
\hline Non-infectious causes & $13(24.5)$ \\
\hline Malignant infiltration ${ }^{* * * *}$ & $2(3.8)$ \\
\hline Pulmonary embolism & $4(7.5)$ \\
\hline Pneumothorax & $2(3.8)$ \\
\hline Cardiac disease & $5(9.4)$ \\
\hline Undetermined & $10(18.8)$ \\
\hline Cure with $\mathrm{AB}$ and/or $\mathrm{AF}$ treatment & $4(7.5)$ \\
\hline
\end{tabular}

AB: Antibiotic; AF: antifungal treatment. ${ }^{*}$ Definitive cause confirmed via microbiological cultures. ${ }^{* *}$ Possible bacterial etiology supported by radiological and clinical findings. ${ }^{* *}$ Definitive diagnosis based on direct observation of resistant mycobacteria in the sputum and positive cultures.

${ }^{* * * *}$ The 2 cases with leukemic infiltration had the M5 and M4/5 subtypes. Diagnoses were based on radiological and clinical findings. 


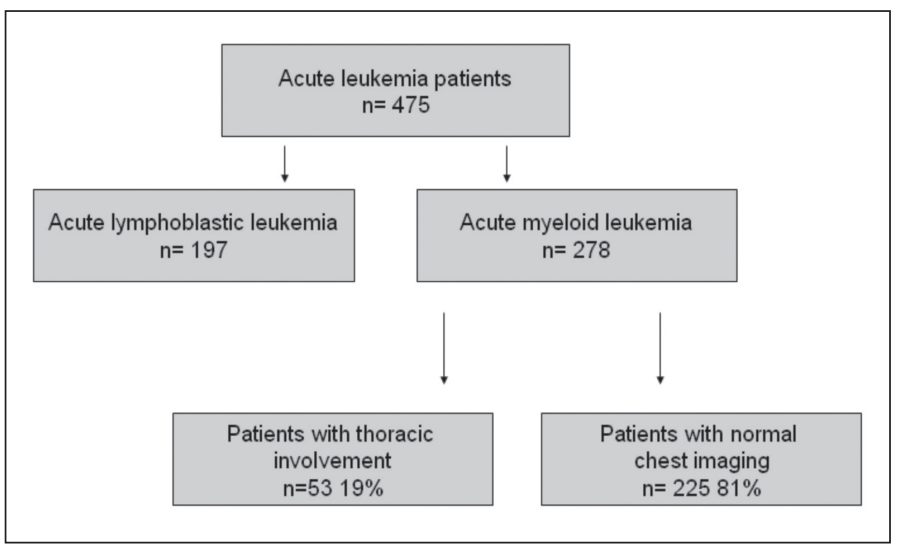

Figure: Leukemia cases included in the study and the distribution of AML patients with pulmonary complications.

\pm 16.3 years, respectively; the difference was significant ( $\mathrm{P}$ $<0.001$ ). Pulmonary complications and gender were not statistically correlated $(\mathrm{P}=0.96)$. Radiologically confirmed pulmonary complications occurred at a higher frequency in the patients with the M4 subtype (32.6\%), though the difference was not significant $(\mathrm{P}=0.55)$. Leukemic infiltration of the lungs was observed in 2 patients with AML M5 ( $n=1)$ and AML M4/5 ( $n=1)$. There wasn't a significant difference in the serum lactate dehydrogenase (LDH) level between the patients with and without pulmonary complications $(P=0.290)$.

In all, $81 \%$ of the patients had parenchymal involvement, $15.1 \%$ had pleural involvement, and 3.8\% had pleuropulmonary involvement. CT findings in the patients with pulmonary lesions were as follows: ground-glass appearance $(n=18)$; nodular opacity $(n=15)$; pneumonic consolidation $(n=9)$; non-homogenous opacity $(n=8)$; fungus ball ( $\mathrm{n}=1)$; nodule with cavity $(\mathrm{n}=1)$; abscess ( $\mathrm{n}$ $=1$ ). Etiological distribution of the pulmonary complications showed that in $56.6 \%$ of the cases the underlying cause was infection. Non-infectious and undetermined causes were responsible for the pulmonary complications in $24.5 \%$ and $18.8 \%$ of the cases, respectively. Clinical response to antibiotic and/or antifungal treatment was achieved in 4 of the patients with pulmonary complications of undetermined origin.

Pulmonary complications were observed at initial presentation in $16(28.9 \%)$ of the patients, whereas in 37 (71.1\%) patients they were observed post chemotherapy. Mortality was $43.8 \%$ in the patients with pulmonary complications at presentation and $24.6 \%$ in those that developed pulmonary complications post chemotherapy. Table 2 summarizes the characteristics of the AML patients with pulmonary complications at presentation and post chemotherapy.

\section{Discussion}

Pulmonary infections are the most common cause of pulmonary radiological findings and are among the most common causes of mortality in AML. [7] Chemotherapy and allogeneic stem cell transplantation are the treatment options in patients in good general condition. The cure rate with chemotherapy alone is low and is usually not durable. Pulmonary complications are the primary cause of mortality, both before and after chemotherapy; therefore, detection of probable pulmonary involvement before commencing chemotherapy could help prevent negative outcomes that might occur during the post-treatment pancytopenic period. As such, predicting the risk of pulmonary complications in AML might play a crucial role in the success of chemotherapy by reducing complicationrelated morbidity and mortality.

Pulmonary complications were observed in 19\% of the present study's patients, which is a lower rate than previously reported. For instance, Ewig et al.[16] observed respiratory findings in 30\% of patients and Chaoui et al. [4] reported a rate of $46 \%$. Unlike the present study, Chaoui et al.'s included patients with a higher median age (median: 55 years; range: $17-85$ years) that had de novo, and secondary acute lymphoid and myeloid leukemias, which might explain why the rate of pulmonary complications was higher in their study. The most frequent cause of pulmonary complications in the present study was infec-

Table 2: Characteristics of the AML patients with pulmonary complications at presentation and post chemotherapy.

\begin{tabular}{|l|c|c|c|} 
& $\begin{array}{c}\text { At presentation } \\
(\mathbf{n}=16)\end{array}$ & $\begin{array}{c}\text { Post chemotherapy } \\
(\mathbf{n}=37)\end{array}$ & P \\
\hline Age (years) & $50 \pm 15.5$ & $32 \pm 11.0$ & 0.001 \\
Neutrophil leukocyte count $\left(\mathrm{mL}^{-1}\right)$ & $373 \pm 423$ & $702 \pm 457$ & 0.001 \\
\hline Hospitalization period (months) & $3.5 \pm 2.7$ & $10 \pm 4.5$ & 0.001
\end{tabular}

AML: Acute myeloid leukemia; F: female; M: male. 
tions (30\%), including those of bacterial and fungal origin; similar findings have been reported. $[4,16,17]$ Rano et al. reported that pulmonary complications were most frequently caused by bacterial infections, followed by fungal infections. [18] Proven or probable invasive pulmonary aspergillosis was observed in 95\% of patients with pulmonary complications in the present study, whereas rates reported in the literature are 5\% in acute leukemias[19] and 6\%-8.3\% in AML[20].

AML is a rare cause of leukemia in individuals aged $<15$ years;[21] it is a disease of late adulthood and the median age of newly diagnosed AML patients is 65 years. [22] Deschler and Lübbert reported an incidence of $1.8 / 100,000$ in patients aged $<65$ years and an incidence of 17/100,000 in patients aged $>65$ years. [23] Mean age of the male and female patients in the present study was 39.2 \pm 16 years and $40.3 \pm 16.5$ years, respectively.

Pulmonary leukemic infiltration was noted in 2 of the present study's AML patients; 1 with the M5 subtype and 1 with the M4/5 subtype. This finding in accordance with the current knowledge. Autopsy studies reported that pulmonary infiltration occurs at a rate of 24\%-64\% in AML M5 cases, versus 5\% for clinically and radiologically diagnosed leukemic lung infiltration.[24,25] No correlation was observed between the serum LDH level and pulmonary complications in the present study, which is agreement with Chaoui et al.,[4] who reported that there wasn't a difference in LDH levels between patients with and without pulmonary complications.

In the present pulmonary complications occurred more frequently in the patients with advanced age particularly $>65$-year-old and there was a statistically significant correlation between age and pulmonary complications ( $\mathrm{P}=$ 0.001 ), which is similar to the findings reported by Rossini et al.[6] Unexplained causes of pulmonary complications were observed in $18.8 \%$ of the present study's patients. Similar findings were reported by Chaoui et al. and Rano et al., who reported that pulmonary complications of unexplained origin occurred in 25\% and 19\% of immunocompromised patients, respectively.[4,18] Pulmonary complications of unidentified origin could be associated with the absence of sufficient diagnostic work-up due to poor general status or severe cytopenias.

In the present study 33\% of the non-infectious causes of pulmonary complications were cardiac pathologies. Cardiac failure-related pulmonary complications occurred primarily during the first week of induction chemotherapy, suggesting that the pulmonary complications were re- lated to chemotherapy or hydration. Cardiovascular dysfunction was reported to occur easily in anemic patients receiving high-volume fluid replacement, and combination chemotherapy consisting of anthracycline and cytosine arabinoside.[26]

The present study's most important findings are as follows:

1. The frequency of pulmonary complications did not differ significantly between AML subtypes;

2. Pulmonary complications at presentation occurred more often in patients of advanced aged with a low absolute neutrophil leukocyte count. Consequently, the baseline absolute neutrophil leukocyte count is an important prognostic factor in patients with advanced age;

3. Ground-glass appearance was the most common nonspecific radiological finding and should be considered as infection in AML patients until proven otherwise;

4. The serum LDH level was observed to be a prognostic factor in the AML patients; however, it is a non-specific marker of pulmonary complications.

In conclusion, the most common pulmonary complication in the present study was infection. We think that the presence of pulmonary complications at diagnosis is a predictor of poor prognosis in AML patients.

\section{Conflict of Interest Statement}

The authors of this paper have no conflicts of interest, including specific financial interests, relationships, and/ or affiliations relevant to the subject matter or materials included.

\section{References}

1. Cheson BD, Cassileth PA, Head DR, Schiffer CA, Bennett JM, Bloomfield CD, Brunning R, Gale RP, Grever MR, Keating MJ. Report of the NCI-sponsored workshop on definitions of diagnosis and response in acute myeloid leukemia. J Clin Oncol 1990; 8: 813-819

2. Pizzo PA. Fever in immucompromised patients. N Engl J Med 1999; 341: 893-900

3. Wade JC. Management of infection in patients with acute leukemia. Hematol Oncol Clin North Am 1993; 7: 293-315

4. Chaoui D, Legrand O, Roche N, Cornet M, Lefebvre A, Peffault de Latour R, Sanhes L, Huchon G, Marie JP, Rabbat A. Incidence and prognostic value of respiratory events in acute leukemia. Leukemia 2004; 18: 670-675 
5. Krowka MJ, Rosenow EC, Hoagland HC. Pulmonary of bone marrow transplantation. Chest 1985; 87: 237-246

6. Rossini F, Verga M, Pioltelli P, Giltri G, Sancassani V, Pogliani EM, Corneo G. Incidence and outcome of pneumonia in patients with acute leukemia receiving first induction therapy with antracyclines-containing regimens. Haematologica 2000; 85: 1255-1260

7. Demirkazik FB, Akin A, Uzun O, Akpinar MG, Ariyürek MO. CT findings in immunocomprimised patients with pulmonary infections. Diagn Interv Radiol 2008; 14: 75-82

8. Wardman AG, Milligan DW, Child JA, Delamore IW, Cooke NJ. Pulmonary infiltrates and adult acute leukaemia: Empirical treatment and survival related to the extent of pulmonary radiological disease. Thorax 1984; 39: 568-571

9. Sverzellati N, Zompatori M, Poletti V, Geddes DM, Hansell DM. Small chronic pneumothoraces and pulmonary parenchymal abnormalities after bone marrow transplantation. J Thorac Imaging 2007; 22: 230-234

10. Bruno C, Minniti S, Vassanelli A, Pozzi-Mucelli R. Comparison of CT features of aspergillus and bacterial pneumonia in severely neutropenic patients. J Thorac Imaging 2007; 22: 160-165

11. Marchiori E, Escuissato DL, Gasparetto TD, Considera DP, Franquet T. "Crazy-Paving" patterns on high resolution CT scans in patients with pulmonary after hematopoietic stem cell transplantation. Korean J Radiol 2009; 10: 21-24

12. Gevenois PA, de Maertelaer V, De Vuyst P, Zanen J, Yernault JC. Comparison of computed density and macroscopic morphomtery in pulmonary emphysema. Am J Respir Crit Care Med 1995; 152: 653-657

13. Subirà M, Martino R, Rovira M, Vazquez L, Serrano D, De La Cámara R. Clinical applicability of the new EORTC/MSG classification for invasive pulmonary aspergillosis in patients with hematological malignancies and autopsy-confirmed invasive aspegillosis. Ann Hematol 2003; 82: 80-82

14. Hughes WT, Armstrong D, Bodey GP, Brown AE, Edwards JE, Feld R, Pizzo P, Rolston KV, Shenep JL, Young LS. 1997 guidelines for the use of antimicrobial agents in neutropenic patients with unexplained fever. Infectious Diseases Society of America. Clin Infect Dis 1997; 25: 551-573
15. Hughes WT, Armstrong D, Bodey GP, Bow EJ, Brown AE, Calandra T, Feld R, Pizzo PA, Rolston KV, Shenep JL, Young LS. 2002 guidelines for the use of antimicrobial agents in neutropenic patients with cancer. Clin Infect Dis 2002; 34: 730-751

16. Ewig S, Glasmacher A, Ulrich B, Wilhelm K, Schäfer H, Nachtsheim KH. Pulmonary infiltrates in neutropenic patients with acute leukemia during chemotherapy, outcome and prognostic factors. Chest 1998; 114: 444-451

17. Rosenow EC 3rd, Wilson WR, Cockerill FR 3rd. Pulmonary disease in immunocompromised host (second of two parts). Mayo Clin Proc 1985; 60: 473-487

18. Rañó A, Agustí C, Jimenez P, Angrill J, Benito N, Danés C, González J, Rovira M, Pumarola T, Moreno A, Torres A. Pulmonary infiltrates in non-HIV immunocompromised patients: a diagnostic approach using non-invasive and bronchoscopic procedures. Thorax. 2001 May;56(5): 379387

19. Segal BH. Aspergillosis. N Engl J Med 2009; 360: 1870-1884

20. Cornet M, Fleury L, Maslo C, Bernard JF, Brücker G. Invasive Aspergillosis Surveillance Network of the Assistance Publique-Hôpitaux de Paris: Epidemiology of invasive aspergillosis in France: A six-year multicentric survey in the greater Paris area. J Hosp Infect 2002; 51: 288-296

21. Aquino VM. Acute myelogenous leukemia. Curr Probl Pediatr Adolesc Health Care 2002; 32: 50-58

22. Forman D, Stockton D, Møller H, Quinn M, Babb P, De Angelis R, Micheli A. Cancer pravalence in UK: Results from the EUROPREVAL study. Ann Oncol 2003; 14: 648-654

23. Deschler B, Lübbert M. Acute myeloid leukemia: Epidemiology and etiology. Cancer 2006; 107 (9): 2099-2107

24. Vlad O, Peddinghaus ME, Rubin R. Acute monocytic leukemia presenting as pulmonary infiltration. Commun Oncol 2008; 5: 328-330

25. Darmon M, Azoulay E. Prognosis of Acute Monocytic Leukemia (French-American-British Classification M5). J Clin Oncol 2005; 23: 1327

26. Briasoulis E, Pavlidis N. Noncardiogenic pulmonary edema: unusual and serious complication of anticancer therapy. Oncologist 2001; 6: 153-161 